\title{
MENINGKATKAN PRESTASI BELAJAR DENGAN METODE KOOPERATIF STUDENTS TEAMS ACHIEVEMENT DIVISION (STAD) PADA PELAJARAN DIAGNOSA PC KELAS XI TKJ SMK BONAVITA
}

\author{
IMPROVING STUDENTS LEARNING ACHIEVEMENTS BY USING COOPERATIVE \\ MODEL OF STUDENTS TEAMS ACHIEVEMENT DIVISION (STAD) ON PERSONAL \\ COMPUTER DIAGNOSING AT CLASS XI TKJ (COMPUTER NETWORK TECHNICS) \\ BONAVITA SECONDARY VOCATIONAL SCHOOL
}

\author{
D.Dedy Prasetya Kristiadi \\ SMK Bonavita Tangerang \\ dedyvhallen.dedy@gmail.com
}

Naskah diterima:25/02/2016, direvisi akhir: 29/03/2016, disetujui: 15 /04/2016

\begin{abstract}
ABSTRAK
Penelitian ini bertujuan untuk meningkatkan prestasi belajar dengan metode kooperatif Students Teams Achievement Division (STAD). Penelitian ini dilakukan pada kelas XI TKJ SMK Bonavita Tangerang tahun pelajaran 2015/2016 dengan metode penelitian tindakan kelas (PTK). Subjek penelitian adalah siswa XI TKJ sebanyak 24 siswa yang diawali dengan test selanjutnya dengan penelitian tindakan kelas terdiri dari dua Siklus. Siklus pertama mengenali kerusakan pada komputer dan jaringan selanjutnya setting ulang jaringan dengan topologi bus. Sebelum diadakan penelitian tindak kelas hasil belajar siswa adalah sebagai berikut. Banyak siswa yang mengikuti ulangan adalah 24 orang, siswa yang tidak tuntas sebanyak 22 orang, siswa yang telah tuntas belajar adalah 2 orang, atau sebesar 8,3 persen. Setelah dilakukan tindakan pada Siklus 1 terdapat kenaikan 25 persen dengan rincian 6 siswa yang telah tuntas belajar. Pada Siklus 2 terdapat kenaikan menjadi 100 persen atau sebanyak 24 siswa telah tuntas belajar. Berdasarkan itu, dapat disimpulkan bahwa metode kooperatif tipe STAD pada pelajaran Diagnosa PC yang terhubung jaringan dapat menaikkan aktifitas dan prestasi belajar kelas XI TKJ 1 SMK Bonavita Tangerang.
\end{abstract}

Kata Kunci: model kerja sama, teknik belajar mengajar kelompok, prestasi belajar, diagnosa PC

\section{ABSTRACT}

This research aimed to improve learning achievement using cooperative method of Students Teams Achievment Division (STAD). The research was done at class XI TKJ in secondary vocational school of Bonavita Tangerang, Banten academic year of 2015/2016 using classroom action research. The research subject consist of 24 students from class XI TKJ. The research began by giving a test and then followed by 2 cycles of classroom action. The first cycle was to recognize damage to the computer and network then resetting the network by bus topology. Before the action was applied, the results were as follows. Among the total number of students taking the test (24 students), 22 students failed, and 2 students passed students. Thus the percentage of fail students was 91 percent. After the action was applied in Cycle 1, there was an increase of 6 students who passed the test, and in Cycle 2 there was an increase to all of the 24 students passed the test. Based on this result, it could be concluded that Cooperative STAD is effective in improving students' learning achievements especially in personal computer diagnose connected to network lessons at class XI TKJ of Bonavita Secondary Vocational School, Tangerang. 
Keywords: cooperative model, Students Teams Achievment Division (STAD), learning achievements, $P C$ diagnosing.

\section{PENDAHULUAN}

PP no. 29 tahun 1990 pasal 3 ayat 2 menetapkan bahwa pendidikan menengah kejuruan mengutamakan penyiapan siswa untuk memasuki lapangan kerja serta mengembangkan sikap profesionalitas. Sedangkan pasal 18 UU no. 20 th. 2003 menetapkan bahwa pendidikan kejuruan merupakan pendidikan menengah yang mempersiapkan peserta didik terutama untuuk bekerja pada bidang tertentu. Hal ini dikarenakan mata pelajaran di SMK sudah disertai dengan praktik keterampilan sehingga tamatan dari SMK akan lebih siap untuk memasuki lapangan kerja.

SMK Bonavita Tangerang adalah salah satu perwujudan upaya pengurangan pengangguran lulusan pendidikan menengah, khususnya jurusan tehnik komputer jaringan yang banyak diminati oleh orangtua agar kelak anaknya dapat langsung bekerja setelah lulus. Pada kenyataannya hasil dari proses belajar tidak sesuai harapan. Permasalahan yang muncul adalah sebagian besar siswa tidak mampu mempraktekkan secara mandiri teori yang disampaikan oleh guru, siswa tidak mampu mempresentasikan apa yang sudah dibuat, kurangnya nilai keaktifan siswa, tidak tercapainya nilai rata-rata KKM yang diharapkan, siswa tidak termotivasi untuk belajar karena belum mengerti tujuan pembelajaran. Tujuan penelitian ini adalah untuk menganalisis alasan digunakannya metode kooperatif STAD dalam meningkatkan hasil belajar siswa kelas XI TKJ. Alasan metode ini digunakan adalah karena metode kooperatif STAD mengandung gagasan untuk memotivasi siswa untuk berprestasi secara tim dengan saling mendukung dan membantu satu sama lain dalam menguasai pengetahuan yang diajarkan oleh guru. Kriteria keberhasilan tindakan yang dilakukan dalam penelitian ini berupa kriteria kualitatif dan kuantitatif. Tindakan dikatakan berhasil apabila semua siswa mengalami peningkatan kemampuan. Bila nilai yang diperoleh siswa lebih bagus daripada nilai yang didapat sebelum tindakan dilakukan, maka tindakan yang dilakukan sudah baik. Nilai siswa dikatakan baik apabila mencapai kriteria ketuntasan minimal yang ditetapkan untuk kompetensi dasar ini, yaitu 75 persen. Kriteria keberhasilan secara kualitatif dapat dilihat apabila nilai siswa lebih bagus daripada sebelum tindakan, maka kualitas simakan siswa juga lebih baik dan tindakan berhasil. Kriteria keberhasilan penelitian ini apabila hasil belajar siswa yang tuntas individu 75 persen, dan klasikal mencapai 85 persen. Kriteria ketuntasan nilai minimal 75.

\section{METODE}


Penelitian ini merupakan penelitian tindakan kelas yang dilakukan sejak bulan April - Mei 2015. Subjek dalam penelitian ini adalah siswa kelas XI TKJ 1 dengan rincian 2 perempuan dan 22 laki-laki. Guru bidang studi, wali kelas dan kepala program TKJ sebagai kolaborator. Ruang yang digunakan adalah ruang kelas dan laboratorium TKJ.

Teknik pengumpulan data dilakukan dengan berbagai cara, antara lain: (i) catatan lapangan; (ii) angket (questionnaire); (iii) daftar cocok atau ceklis (checklist); (iv) lembar pengamatan (observasi); (v) wawancara (interview); dan (vi) tes hasil belajar. Selain itu digunakan teknik komunikasi langsung yang mengharuskan peneliti mengadakan kontak langsung secara lisan atau tatap muka dengan sumber data, baik dalam situasi yang sebenarnya maupun dalam situasi yang sengaja dibuat untuk keperluan tersebut. Pendekatan penelitian dilakukan secara kuantitatif yang bertujuan untuk mengetahui tingkat atau derajat hasil belajar siswa. Penelitian ini dimulai dengan melihat nilai mid-semester siswa, pelaksanaan disusul post-test, tanya jawab dengan siswa tentang kendala pemahaman pada teori maupun praktek. Temuan itu dicatat oleh peneliti selanjutnya dicarikan metode yang tepat berdasar kesulitan dan karakteristik siswa. Peneliti dan kolaborator menyiapkan skenario pengajaran yang dimulai dengan persiapan alat,materi dan berkas penilaian. Selanjutnya melakukan Siklus pengajaran yang terdiri dari dua Siklus yaitu Siklus 1 yang berisi 6 fase dan Siklus 2 yang memiliki 6 fase. Data yang diperoleh dari hasil belajar diolah dalam bentuk nilai dan prosentase ketuntasan.

\section{KAJIAN LITERATUR}

\section{Belajar, Pembelajaran dan Prestasi}

Belajar merupakan kegiatan yang kompleks belajar adalah perubahan dalam disposisi manusia atau kemampuan yang berlangsung selama satu waktu dan yang tidak semata-mata disebabkan oleh perubahan pertumbuhan. Jenis perubahan tersebut meliputi perubahan tingkah laku setelah individu mendapatkan berbagai pengalaman (Gagne dalam Dimyati, 2006). Belajar dapat disimpulkan sebagai proses penguasaan perubahan atas rangsangan dan respon yang bersifat permanen, baik dalam pemahaman, sikap, pengetahuan, informasi, kemampuan dan keterampilan yang diperoleh melalui pengalaman. Belajar dalam penelitian ini adalah proses perubahan tingkah laku peserta didik terhadap pelajaran Mendiagnosa PC yang terhubung jaringan yang berlangsung selama kurun waktu tertentu, meliputi perubahan pengetahuan, pemahaman, keterampilan, nilai dan sikap melalui pengalaman.

\section{Pembelajaran}

Pembelajaran, adalah suatu proses komunikasi dua arah, yakni proses mengajar yang dilakukan oleh guru sebagai pendidik, sedangkan belajar merupakan proses penyerapan ilmu pengetahuan yang dilakukan oleh peserta didik atau siswa. Pembelajaran 
ialah proses membelajarkan siswa menggunakan asas pendidikan maupun teori belajar yang merupakan penentu utama keberhasilan pendidikan (Sagala, 2007). Selain itu, pembelajaran merupakan proses yang diselenggarakan oleh guru untuk membelajarkan siswa untuk memperoleh dan memproses pengetahuan, keterampilan, dan sikap (Dimyati, 2006: 157). Dengan demikian pembelajaran adalah suatu proses belajar dan mengajar yang terjadi antara guru dan siswa, bertujuan bagaimana terjadinya perubahan pengetahuan, sikap dan keterampilan. Pembelajaran yang dimaksudkan dalam penelitian ini sebagai proses yang dilakukan oleh guru dan siswa dalam mempelajari materi mendiagnosa pc yang terhubung jaringan dengan menggunakan material (buku kurikulum, buku pelajaran, rencana pembelajaran, buku panduan praktik mendiagnosa PC, papan tulis, spidol, LCD); fasilitas dan perlengkapan (mencakup ruang kelas, Lab TKJ, komputer, internet) dan prosedur yang meliputi jadwal, metode penyampaian, praktik, ulangan, dalam rangka mencapai tujuan belajar, yakni terjadinya perubahan pengetahuan, keterampilan dan sikap siswa setelah mempelajari Mendiagnosa PC yang terhubung jaringan melalui internet dengan menggunakan teknologi informasi.

\section{Media Pembelajaran}

Media pembelajaran adalah sarana fisik untuk menyampaikan isi/materi pembelajaran seperti buku, film, video dan sebagainya (Briggs,
1970). Media pembelajaran adalah segala sesuatu yang digunakan untuk menyalurkan pesan dan dapat merangsang pikiran, perasaan, perhatian dan kemauan si belajar sehingga dapat mendorong terjadinya proses belajar yang disengaja, bertujuan dan terkendali (Karim, 2007). Dari ketiga pendapat di atas disimpulkan bahwa media pembelajaran adalah segala sesuatu yang dapat menyalurkan pesan, dapat merangsang fikiran, perasaan, dan kemauan peserta didik sehingga dapat mendorong terciptanya proses belajar pada diri peserta didik. Secara rinci fungsi penggunaan media dalam proses pembelajaran: (i) menarik perhatian siswa, (ii) membantu untuk mempercepat pemahaman dalam proses pembelajaran, (iii) memperjelas penyajian pesan agar tidak besifat verbalistis (dalam bentuk kata-kata tertulis atau lisan), (iv) mengatasi keterbatasan ruang, (v) pembelajaran lebih komunikatif dan produktif, (vi) waktu pembelajaran dapat dikondisikan, (vii) menghilangkan kebosanan siswa dalam belajar, (viii) meningkatkan motivasi siswa dalam mempelajari sesuatu/ menimbulkan gairah belajar, (ix) melayani gaya belajar siswa yang beraneka ragam, serta, (x) meningkatkan kadar keterlibatan siswa dalam pembelajaran (Fathurrohman, 2007).

\section{Prestasi}

Prestasi adalah hasil yang telah dicapai (dilakukan, dikerjakan, dan sebagainya) (WJS. Poerwadarminta dalam Djamarah, 1994). 
Mas'ud Khasan Abdul Qahar, memberi batasan prestasi dengan apa yang telah diciptakan, hasil pekerjaan, hasil yang menyenangkan hati yang diperoleh dengan jalan keuletan kerja. pengertian prestasi yang telah dibahas sebelumnya dapat disimpulkan bahwa pengertian prestasi adalah hasil dari suatu kegiatan yang telah dikerjakan, diciptakan, yang menyenangkan hati yang diperoleh dengan jalan keuletan kerja.

\section{Pembelajaran Kooperatif}

Pembelajaran kooperatif adalah model pembelajaran dimana siswa belajar dalam kelompok-kelompok kecil yang memiliki tingkat kemampuan berbeda (Khoiri, 2010). Cooperative Learning berasal dari kata cooperative yang artinya mengerjakan sesuatu secara bersama-sama dengan saling membantu satu sama lain sebagai satu kelompok satu tim (Isjoni, 2010). Pembelajaran kooperatif merupakan model pembelajaran yang dirancang untuk membelajarkan kecakapan akademik, sekaligus ketrampilan sosial (Riyanto, 2010). Cooperative learning merupakan kegiatan belajar siswa yang dilakukan dengan cara berkelompok. Model pembelajaran kelompok adalah rangkaian kegiatan belajar yang dilakukan oleh siswa dalam kelompok-kelompok tertentu untuk mencapai tujuan pembelajaran yang telah dirumuskan. Dari beberapa pendapat ahli di atas dapat disimpulkan bawa pembelajaran kooperatif adalah bentuk pembelajaran yang dilakukan oleh siswa secara berkelompok terdiri dari empat atau lima orang dengan struktur heterogen, bekerja sama secara kolaboratif untuk memcahkan suatu masalah.

\section{Prinsip Pembelajaran Kooperatif}

Terdapat lima prinsip yang mendasari pembelajaran kooperatif (Riyanto, 2010). Pertama, adanya saling ketergantungan positif, yakni anggota kelompok menyadari pentingnya kerja sama dalam mencapai tujuan. Kedua, antar anggota berinteraksi dengan saling berhadapan. Ketiga, setiap anggota kelompok harus belajar dan aktif memberikan kontribusi untuk mencapai keberhasilan kelompok. Keempat, harus menggunakan keterampilan bekerja sama dan bersosialisasi. Antara siswa mampu berkolaborasi perlu adanya bimbingan guru. Kelima, siswa perlu menilai bagaimana mereka bekerja sama secara efektif.

\section{Langkah-langkah Pembelajaran}

\section{Kooperatif}

Pembelajaran kooperatif memiliki tujuh langkah (Riyanto, 2010). Pertama, memberikan informasi dan menyampaikan tujuan sera skenario pembelajaran. Kedua, mengorganisasikan siswa/peserta didik dalam kelompok kooperatif. Ketiga, membimbing siswa untuk melakukan kegiatan/ berkooperatif. Keempat, melakukan evaluasi. Kelima, memberikan penghargaan. Dengan kata lain, pendapat tersebut mengandung makna bahwa langkah-langkah pembelajaran kooperatif mencakup penyampaikan materi 
dan pelaksanaan pembelajaran, pembentukan kelompok siswa, pemberian penilaian/evaluasi, dan pemberian penghargaan atau pengakuan tim.

\section{Model-model Pembelajaran Kooperatif}

Ada beberapa model pembelajaran kooperatif, walaupun prinsip dasar dari pembelajaran kooperatif ini tidak berubah (Mulya, 2012). Model-model tersebut adalah Student Teams Achievment Division (STAD), Team Game Tournament (TGT), Jigsaw, kelompok Investigasi, Students Team Achievement Division (NHT), Think-Pair-Share (TPS), Debat, dan Picture and Picture (PP). Dalam penelitian ini, dilakukan penerapan pembelajaran kooperatif model Students Teams Achievement Division (STAD). Alasan pemilihan metode ini adalah adanya gagasan memotivasi siswa supaya dapat saling mendukung dan membantu satu sama lain dalam menguasai pengetahuan yang diajarkan oleh guru. Jika para siswa ingin agar timnya mendapatkan penghargaan tim, mereka harus membantu teman satu timnya untuk mempelajari materi Diagnosa PC yang terhubung jaringan.

\section{Pembelajaran dengan model STAD}

STAD merupakan tipe cooperative learning yang menekankan interaksi siswa untuk saling memotivasi dan saling membantu dalam menguasai materi dan pencapaian prestasi secara maksimal dan juga merupakan salah satu metode atau pendekatan dalam pembelajaran kooperatif yang sederhana dan baik untuk guru yang baru mulai menggunakan pendekatan kooperatif dalam kelas, STAD juga merupakan suatu metode pembelajaran yang efektif (Slavin, 2010).

Dalam STAD, para siswa siswa dibagi dalam kelompok belajar yang terdiri atas empat orang yang berbeda-beda kemampuan, jenis kelamin, latar belakang etniknya. Guru menyampaikan pelajaran, lalu siswa bekerja dalam team mereka untuk memasikan bahwa semua anggota team menguasai pelajaran. Selanjutnya, semua siswa mengerjakan kuis mengenai materi secara sendiri-sendiri, dimana pada saat itu mereka tidak diperbolehkan untuk saling membantu. Skor kuis para siswa dibandingkan dengan rata-rata pencapaian mereka sebelumnya, dan kepada masingmasing team akan diberikan poin berdasarkan tingkat kemajuan yang diraih siswa dibandingkan hasil yang dicapai sebelumnya. Poin ini kemudian dijumlahkan untuk memperoleh skor team dan team yang berhasil memenuhi kriteria tertentu akan mendapat sertifikat dan penghargaan lainnya.

Gagasan utama STAD adalah untuk memotivasi siswa supaya dapat saling mendukung dan membantu satu sama lain dalam menguasai pengetahuan yang diajarkan oleh guru. Jika para siswa ingin agar teamnya mendapat penghargaan team, mereka harus membantu teman satu teamnya untuk mempelajari materinya. 
Materi Diagnosa PC yang terhubung Jaringan

Hakekat diagnosa PC yang terhubung jaringan adalah mendiagnosa permasalahan yang terjadi pada komputer personal dan jaringan berbasis luas atau wireless dilakukan untuk mengetahui bagian-bagian perangkat hardware dan software yang kemungkinan mengalami kerusakan atau gangguan. Mendiagnosa kerusakan dapat dilakukan secara hardware maupun secara software dengan indikasiindikasi yang dapat diamati.

Pembelajaran inilah yang dilakukan oleh siswa kelas XI TKJ 1 demi menunjang pengetahuan sesuai jurusannya dan matapelajaran yang bersangkutan. Dalam pembelajaran ini dibutuhkan perhatian dan keseriusan dalam prosesnya agar siswa dapat menyerap apa yang disampaikan dan ilmu yang terkandung di dalamnya.

\section{HASIL DAN PEMBAHASAN}

\section{PraSiklus}

Berdasarkan hasil pra-observasi yang dilaksanakan pada tanggal 2 April 2015, guru lebih dominan menggunakan metode ceramah, dan mencatat materi di papan tulis, sehingga siswa kurang bersemangat dalam pelaksanaan pembelajaran. Banyak di antara siswa tidak memperhatikan guru menjelaskan, dan ada juga yang berbicara pada teman sebangkunya. Hasil post-test yang dilaksanakan pada tanggal 2 April 2015, menunjukkan bahwa hanya 2 siswa yang tuntas. Oleh karena itu, diperlukan strategi yang dapat meningkatkan hasil belajar siswa melalui model kooperatif

Perencanaan
\begin{tabular}{|c|l|l|}
\hline NO & \multicolumn{1}{|c|}{ Hari/ Tanggal } & \multicolumn{1}{c|}{ Kegiatan } \\
\hline 1 & 2 April 2015 & Post Test (Observasi Awal) \\
\hline 2 & $6-10$ April 2015 & Melakukan perencanaan bersama kolaborator \\
\hline 3 & $13-17$ April 2015 & Mempersiapkan sarana laboratorium TKJ \\
\hline 4 & $20-23$ April 2015 & Mempersiapkan berkas penilaian, validasid dl \\
\hline 5 & selasa, 7-5-2015 & Pertemuan I Siklus 1 kelas TKJ 1 \\
\hline 6 & Kamis, 9-5-2015 & Pertemuan 2 Siklus 1 kelas TKJ1 (Lanjutan) \\
\hline
\end{tabular}
Pertemuan 1 Pkl 07.15-08.45

Tabel 1.

\section{Siklus 1}

Siklus ini dilakukan dalam 2 kali pertemuan dan dilakukan pada hari Selasa tanggal 7 Mei 2015 dari pukul 07.15-08.45 wib dilanjutkan hari Kamis tanggal 9 Mei 2015 dengan jam yang sama. Siklus I ini membahas tentang materi 5 Indikator kerusakan jaringan. Siklus ini terdiri atas tahap perencanaan, tindakan, observasi, dan refleksi. Pada tahap perencanaan dirancang perangkat dan instrument pembelajaran (rencana pelaksanaan pembelajaran model kooperatif Students Team Achievement Division, LKS, post test, dan lembar observasi). Perangkat ini disusun oleh peneliti dan didiskusikan bersama guru mata pelajaran Diagnosa Pc yang terhubung jaringan SMK Bonavita Tangerang. Sebelum tahap tindakan pada Siklus I, terlebih dahulu dilakukan post test dengan alokasi waktu 45 menit. Post test ini dilakukan untuk melihat kemampuan awal siswa sebelum dilakukan tindakan. Pemberian post test diberikan pada tanggal 2 April 2015, untuk melihat 
kemampuan awal siswa dan pembetukan kelompok belajar siswa.
Hasil post test tidak ada satu pun siswa yang mencapai ketuntasan belajar (Tabel 1).

Tabel 2. Post test Pra Siklus

\begin{tabular}{|c|c|c|c|c|c|c|c|c|c|c|c|c|}
\hline \multirow{3}{*}{ No. } & \multirow{3}{*}{ Napps Sisowe. } & \multirow{3}{*}{ Agams } & \multicolumn{5}{|c|}{ Pra Tipdaken. } & \multicolumn{3}{|c|}{ Siklus. 1} & \multicolumn{2}{|c|}{ Siklus. 2} \\
\hline & & & \multicolumn{3}{|c|}{ Wharian. } & \multicolumn{2}{|c|}{ PRAKTEK } & \multirow{2}{*}{$\begin{array}{c}\text { Nillaj } \\
\mathrm{TM} \\
\end{array}$} & \multirow{2}{*}{$\begin{array}{l}\mathrm{fkec} \\
\mathrm{TM}\end{array}$} & \multirow{2}{*}{$\begin{array}{l}\text { Nolai } \\
\text { Akbir. }\end{array}$} & \multirow[t]{2}{*}{ Nilpi } & \multirow[t]{2}{*}{ SKOR } \\
\hline & & & JK & 1 & Sker. & 1 & Sker. & & & & & \\
\hline 1 & AMSAL GENARETH & Kristen & \multirow{2}{*}{ L } & 50 & 20 & 78 & 32 & 85 & 35 & 70 & 85 & 35 \\
\hline 2 & CANSANDIKING F & Kristen & & 40 & 16 & 67 & 27 & 75 & 31 & 62 & 78 & 33 \\
\hline 3 & CLAVIANUS JUNEARDO & Kristen & \multirow{2}{*}{$\begin{array}{l}\mathrm{L} \\
\mathrm{L}\end{array}$} & 58 & 24 & 34 & 14 & 80 & 34 & 67 & 75 & 31 \\
\hline 4 & CRIS SUN RAY & Kristen & & 65 & 27 & 55 & 22 & 82 & 35 & 67 & 80 & 34 \\
\hline 5 & DAVID & Katelik. & \multirow{2}{*}{$\begin{array}{l}\mathrm{L} \\
\mathrm{p}\end{array}$} & 60 & 25 & 55 & 22 & 60 & 25 & 67 & 82 & 35 \\
\hline 6 & FILIA & Kristen & & 45 & 18 & 45 & 18 & 75 & 31 & 59 & 86 & 36 \\
\hline 7 & FRANSISKUS WAHYU P & Katelik. & \multirow{2}{*}{$\begin{array}{l}\mathrm{L} \\
\mathrm{L}\end{array}$} & 35 & 14 & 38 & 15 & 75 & 31 & 52 & 78 & 33 \\
\hline 8 & HANDREAS & Kristen & & 68 & 28 & 40 & 16 & 75 & 31 & 64 & 80 & 34 \\
\hline 9 & HANSEL MARCELINDO & Kristen & \multirow{3}{*}{$\begin{array}{l}\mathrm{L} \\
\mathrm{L} \\
\mathrm{L}\end{array}$} & 75 & 31 & 75 & 31 & 80 & 33 & 81 & 96 & 40 \\
\hline 10 & HEZRON HEZEKIAH L & Kristen & & 60 & 25 & 55 & 22 & 80 & 33 & 70 & 88 & 37 \\
\hline 11 & JAYA PARAMITHA & Buddha & & 27 & 11 & 65 & 27 & 60 & 25 & 54 & 75 & 31 \\
\hline 12 & JIMMY ANGGA G & Islam & \multirow{3}{*}{$\begin{array}{l}\text { L } \\
\text { L } \\
\text { L }\end{array}$} & 50 & 20 & 60 & 25 & 75 & 31 & 66 & 86 & 36 \\
\hline 13 & JUFRENSIUS BARASA & Kristen & & 60 & 25 & 80 & 33 & 80 & 33 & 76 & 88 & 37 \\
\hline 14 & LAURENSIUS JEFFREY C & Katellk & & 60 & 25 & 70 & 29 & 88 & 36 & 73 & 80 & 34 \\
\hline 15 & REUBEN HANS & Buddha & \multirow{2}{*}{ L } & 60 & 25 & 75 & 31 & 78 & 32 & 75 & 78 & 33 \\
\hline 16 & RICKY YULLANTO & Katellk & & 65 & 27 & 70 & 29 & 78 & 32 & 75 & 82 & 35 \\
\hline 17 & ROMISUGIANTO & Buddha & \multirow{2}{*}{$\begin{array}{l}\mathrm{L} \\
\mathrm{P}\end{array}$} & 68 & 28 & 75 & 31 & 78 & 32 & 73 & 86 & 36 \\
\hline 18 & SHARREN NATSHA & Kristen & & 45 & 18 & 75 & 31 & 68 & 28 & 63 & 75 & 31 \\
\hline 19 & STEFANUS DEO REGYL & Katellk. & \multirow{2}{*}{$\begin{array}{l}\mathrm{L} \\
\mathrm{L}\end{array}$} & 75 & 31 & 78 & 32 & 90 & 37 & 74 & 78 & 33 \\
\hline 20 & THEDORE LEONARDO & Katelik. & & 60 & 25 & 70 & 29 & 85 & 35 & 68 & 76 & 32 \\
\hline 21 & THOMAS ARDIPH & Kristen & \multirow{2}{*}{ L } & 40 & 16 & 75 & 31 & 50 & 20 & 63 & 78 & 33 \\
\hline 22 & WILLY ANTONIUS & Katelik. & & 55 & 22 & 78 & 32 & 75 & 31 & 64 & 80 & 34 \\
\hline 23 & YOSEP SAPUTRA & Kristen & \multirow{2}{*}{ L } & 40 & 16 & 50 & 20 & 85 & 35 & 71 & 85 & 35 \\
\hline 24 & YUDHI HENDRA & Islam & & 75 & 31 & 80 & 33 & 90 & 37 & 75 & 88 & 37 \\
\hline
\end{tabular}

Tahap selanjutnya adalah tindakan dengan menggunakan model kooperatif STAD. Tindakan dilakukan dengan alokasi waktu selama 2 x 90 menit. Penyampaian materi dilakukan di kelas sedangkan diskusi dilakukan di laboratorium TKJ. Pertama-pertama guru membuka pelajaran dengan mengabsen siswa. Selanjutnya, menyampaikan tujuan pembelajaran dan memotivasi siswa dengan mengulas materi sebelumnya, yaitu indikator kerusakan pada jaringan. Kegiatan ini memakan waktu kurang lebih 15 menit.

Dalam pembelajaran kooperatif $S T A D$ terdapat 6 fase. Fase 1 adalah pelaksanaan pembelajaran berlangsung di kelas, disampaikan tujuan dan motivasi siswa dengan mengulas sedikit materi sebelumnya, yakni dengan memberi pertanyaan seperti bagaimanakah bentuk topologi bus? Siswa masih belum aktif dalam menjawab pertanyaan-pertanyaan oleh guru dan mereka sibuk untuk mencari jawaban. Setelah beberapa lama, barulah mereka menjawab pertanyaan guru. Waktu yang digunakan dalam fase 1 ini selama sekitar 15 menit.

Fase 2 (di kelas), guru menyampaikan informasi kepada siswa selama 30 menit. Guru 
menjelaskan tentang indikator kerusakan pada server dan work station, hub/switch, Network Interface Card, kabel dan konektor. Selanjutnya siswa diminta untuk mengamati switch, Network Interface Card dan siswa diberi kesempatan untuk bertanya dan berpendapat. Selanjutnya, guru memberikan contoh kerusakan server, kartu jaringan yang rusak dan switch yang rusak melalui computer yang terhubung internet. Guru juga memberikan solusi penanganan kerusakan dan memberi contoh bila server sudah baik.

Pada fase 3 (di kelas) dilakukan pembentukan kelompok belajar. Pada saat pembacaan kelompok, suasana kelas menjadi kurang kondusif karena siswa berharap menjadi anggota kelompok sesuai harapannya. Waktu yang dibutuhkan bertambah 10 menit. Pada saat penempatan kelompok guru meminta ketua kelas mengatur anggota kelasnya. Daftar kelompok sudah disusun sebelumnya dan ketua kelas bertugas untuk memastikan anggota kelompok berada pada kelompoknya. Setelah siswa berada dalam kelompoknya masingmasing maka guru menjelaskan mekanisme pembelajaran.

Fase 4 (di lab praktikum TKJ), Guru membagikan soal diskusi kelompok belajar siswa berupa Quiz. Pada fase ini guru hanya memberikan instruksi kepada siswa untuk menyelesaikan soal diskusi. Pada saat diskusi guru memberikan waktu 30 menit untuk menyelesaikan diskusi.
Fase 5 (di kelas), tahap evaluasi, dilakukan pada hari kamis tanggal 9 Mei 2015. Waktu yang diperlukan adalah 60 menit, bagi 6 kelompok masing-masing mendapatkan kesempatan selama 10 menit. Guru memanggil nomor kelompok yang akan mempresentasikan di depan kelas. Kelompok yang pertama maju yaitu kelompok 6. Kelompok 6 mendapatkan bahan diskusi mengenai kerusakan server. Selanjutnya setiap siswa diminta untuk bertanya atau menguji anggota kelompok yang sedang presentasi.Hanya terdapat 3 siswa yang memberi komentar.Guru belum memberikan apresiasi berupa komentar yang memotivasi siswa. Selanjutnya kelompok 5,4,3,2 dan 1.

Fase 6 adalah pemberian penghargaan kepada siswa. Selama 15 menit guru memberi komentar jawaban kelompok dan kurang memberikan penghargaan kepada siswa baik yang menjawab, memberikan tanggapan, maupun kelompok yang telah berpresentasi di depan kelas. Guru cenderung mengkoreksi siswa dan tidak memberi motivasi.

Pada kegiatan penutup selama 15 menit berisi kesimpulan tentang hasil pembelajaran. Guru menanyakan kepada siswa indikasi kerusakan koneksi pada server. Hanya 4 siswa yang mampu menjawab dengan baik dari pertanyaan yang disampaikan guru. Selanjutnya, guru memberikan post-test untuk mengukur hasil belajar siswa. 
Pada tahap ke-tiga, observasi, guru melakukan tindakan, sedangkan peneliti bertugas sebagai observer. Tujuan dari observasi dalam penelitian ini yaitu untuk memperoleh gambaran lengkap dan objektif tentang perkembangan proses dan pengaruh tindakan yang dipilih terhadap pembelajaran yang dilakukan pendidik dalam menyampaikan materi indikator kerusakan pada server dan work station, hub/switch, Network Interface Card, kabel dan konektor dengan model kooperatif STAD. Secara lengkap hasil observasi sebagai berikut. Pada Siklus 1, terdapat fase yang belum dilakukan oleh guru, yaitu fase 4 mengenai bimbingan guru kepada siswa dalam kelompok belajar mereka. Pada saat menyampaikan informasi (Fase 2) guru terlihat kurang menguasai perbaikan jaringan, sehingga terlihat gugup yang mengakibatkan siswa berasumsi negatif dan menyepelekan. Pada saat pengorganisasian kelompok, suasana kelas menjadi tidak kondusif karena siswa tidak terbiasa dengan pembagian kelompok. Pada saat menyelesaikan tugas, terlihat hanya 2 kelompok yang melaksanakan diskusi dengan baik, sedangkan 4 kelompok lainnya sibuk dengan peralatan peraga yang diletakkan di atas meja guru. Pada saat membahas hasil kerja kelompok, terdapat komentar atau tanggapan siswa yang tidak sesuai dengan materi. Guru kurang memberikan penghargaan kepada siswa atas tanggapan maupun pertanyaan. Berdasarkan hasil observasi pada tindakan, peneliti melakukan refleksi dengan guru pada Siklus I, walaupun hasil belajar dan proses pembelajaran sudah mengalami sedikit perubahan, kekurangan-kekurangan masih ditemui.

Hasil refleksi peneliti pada guru, yaitu sebagai berikut. Pada Siklus 1 guru tidak pernah menanyakan kepada siswa apakah LKS yang dibagikan sudah dipelajari. Pada Siklus 2 guru terlebih dahulu menanyakan kepada siswa tentang LKS. Pada saat menyampaikan informasi (Fase 2) guru terlihat kurang menguasai perbaikan jaringan, sehingga terlihat gugup yang mengakibatkan siswa berasumsi negatif dan menyepelekan. Pada Siklus 2 terlihat Guru lebih mempersiapkan materi. Pada saat pengorganisasian kelompok, suasana kelas menjadi tidak kondusif karena siswa tidak terbiasa dengan diskusi kelompok; pada Siklus 2 terlihat siswa mulai tertib karna instruksi guru lebih terinci. Guru belum membimbing siswa dalam kelompok ketika diskusi kelompok. Hal ini dikarenakan guru belum pernah melaksanakan model kooperatif STAD. Pada Siklus 2, guru lebih siap membimbing kelompok belajar siswa untuk menyelesaikan soal-soal diskusi yang terdapat pada LKS. Sebelumnya siswa belum dapat berinteraksi dengan siswa lain dalam berdiskusi kelompok, sehingga masih banyak terdapat kelompok yang pasif. Hal ini dikarenakan siswa minder dan jarang melakukan diskusi kelompok. Solusinya, pada Siklus 2 guru lebih memberikan motivasi dan mendorong siswa untuk dapat bekerja sama dengan kelompoknya. Siswa tidak terbiasa 
untuk bertanya pada teman dalam kelompok. Pada sikus 2 guru mulai mampu memberikan pernyataan yang dapat merangsang siswa untuk bertanya dan menjawab pertanyaan yang diberikan. Guru jarang memberikan penghargaan kepada siswa yang telah menjawab pertanyaan maupun memberikan tanggapan. Pada Siklus 2 guru memberikan penghargaan kepada siswa yang mengemukakan pendapat dan menjawab pertanyaan setelah memberikan pencerahan tentang masalah yang baru dibahas dalam diskusi. Untuk mengetahui hasil belajar siswa pada Siklus I diberikan post-test. Kemampuan akhir siswa dalam menguasai materi Diagnosa PC yang terhubung jaringan dengan sub materi indikator kerusakan pada server dan work station, hub/switch, Network Interface Card, kabel dan konektor dengan model kooperatif $S T A D$. Setelah melalui pembelajaran dengan tindakan kelas berupa pembelajaran dengan model kooperatif STAD pada Sikus I mengalami peningkatan (Tabel 2).

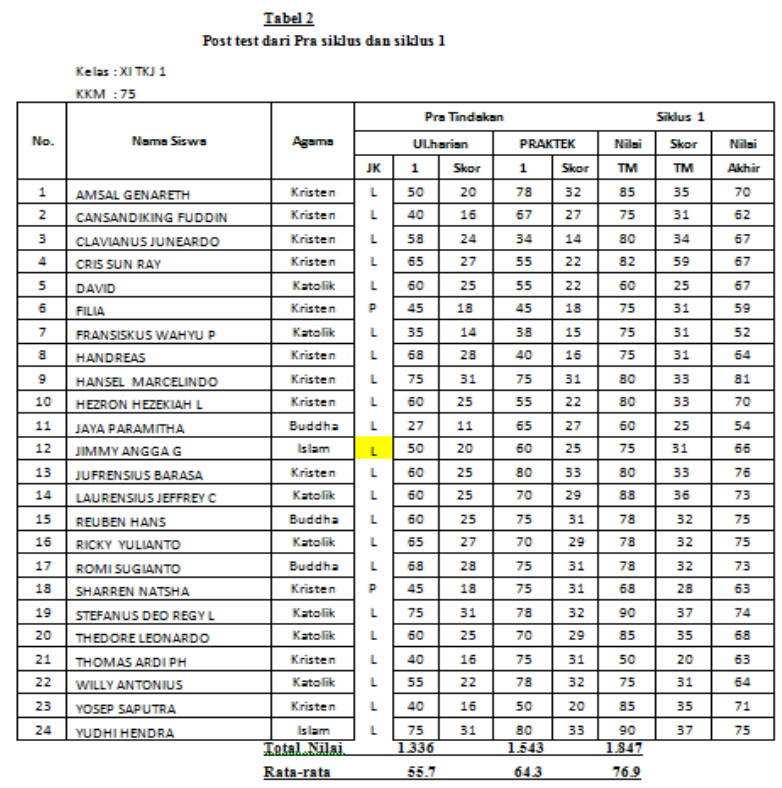

Dari Tabel 2, dapat dilihat perkembangan hasil belajar yang diperoleh oleh siswa saat diberikan pretest dan post test pada Siklus I. Siswa yang mengalami ketuntasan belajar atau yang memperoleh nilai ketuntasan 75-100 pada Siklus I sekitar 5 siswa dari jumlah 24 siswa dan prosentase siswa yang tuntas yaitu 20,83 persen. Hasil tindakan pada Siklus I menunjukkan bahwa hasil belajar yang didapat belum mencapai indikator yang ditentukan untuk hasil belajar (>50persen dari siswa yang mencapai ketuntasan belajar KKM sebesar 75 pada materi yang disampaikan) dan pada proses pembelajaran masih banyak kekurangan dan berdasarkan hasil kesepakatan antara peneliti dengan guru Diagnosa PC SMK Bonavita Tangerang, diputuskan untuk melanjutkan ke Siklus 2

\section{Siklus 2}

Siklus 2 terdiri atas 2 kali pertemuan dan dilaksanakan pada hari Kamis, 21 Mei 2015 dan Kamis, 28 Mei 2015 dengan alokasi waktu $2 \times 90$ menit dengan materi yang diajarkan adalah materi perbaikan kerusakan pada server dan work station, hub/switch, Network Interface Card, kabel dan konektor. Lokasi belajar dilakukan di kelas dan di laboratorium TKJ. Tahap-tahap yang dilakukan pada Siklus 2 sama dengan tahap Siklus I, yaitu 
perencanaan, tindakan, observasi, dan diakhiri dengan refleksi. Perencanaan merupakan kegiatan lanjutan dari Siklus I. Berdasarkan permasalahan dan solusi yang sudah didiskusikan oleh peneliti dan guru maka disusun kegiatan pembelajaran Siklus 2. Tahap-tahap kegiatan pembelajaran sama dengan Siklus I, namun sebelum dilaksanakan Siklus 2 siswa diminta membaca kembali materi sebelumnya dengan memanfaatkan tehnologi informasi berupa internet yang disediakan di sekolah. Hal ini bertujuan agar siswa mempersiapkan materi sebelum disampaikan oleh guru sehingga waktu belajar dapat lebih longgar dan siswa memiliki kesempatan menggunakan internet dengan leluasa. Tindakan pada Siklus 2 sudah lebih baik dari Siklus I. Dimulai dengan kegiatan pendahuluan sama halnya dengan Siklus 1 yaitu guru mengulas materi yang telah disampaikan pada Siklus I tentang materi indikator kerusakan pada server dan work station, hHub/switch, Network Interface Card, Kabel dan konektor. Pada saat mengulas materi, siswa terlihat aktif dalam menjawab pertanyaan-pertanyaan yang diajukan oleh guru tentang materi sebelumnya. Setiap pertanyaan yang diberikan guru langsung dijawab oleh siswa. Kemudian dilanjutkan dengan menyampaikan tujuan pembelajaran.

Dalam Fase 1, terlihat lebih baik dari siklus sebelumnya, hal ini terlihat dari argumen siswa ketika guru menanyakan tentang server dan topologi yang digunakan untuk jaringan. Pada
Fase 1 ini dibutuhkan waktu 15 menit. Fase 1, 3, 5 dan 6 dilakukan di kelas sedangkan Fase 2 dan 4 dilakukan di laboratorium TKJ.

Dalam Fase 2, guru menjelaskan penanganan perbaikan koneksi jaringan dimulai dari server, hub/switch dan kartu jaringan selama 30 menit. Selanjutnya selama 20 menit siswa diminta membuka referensi tentang materi dari internet agar dapat menemukan pengembangan solusi. Selanjutnya siswa diminta untuk mencatat halhal penting yang ditemukan berkaitan dengan solusi perbaikan. Siswa dapat menanyakan hal tersebut kepada guru dan terlihat guru lebih siap menjawab dibandingkan pada Siklus 1 fase yang sama.

Pada Fase 3, pada saat pembagian kelompok, suasana kelas lebih kondusif bahkan cenderung ingin lebih cepat masuk dalam kelompok. Tanpa menunggu waktu lama, kelompok sudah terbentuk. Kelompok pada Siklus 2 berbeda dengan kelompok pada Siklus 1. Setelah pembagian kelompok, selanjutnya kelompok mengambi bahan praktek kemudian guru menjelaskan mekanisme pembelajaran pada saat evaluasi. Pengorganisasian kelompok membutuhkan waktu kurang dari 5 menit.

Pada Fase 4, guru memberikan bimbingan belajar pada setiap kelompok dalam diskusi untuk menyelesaikan soal yang diberikan kelompok belajar siswa. Pada fase ini guru terlihat sangat siap dengan bimbingan di setiap kelompok. Waktu yang dibutuhkan untuk diskusi ini adalah 30 menit. Terlihat seluruh 
anggota kelompok ikut aktif dalam diskusi. Selanjutnya tersisa waktu 10 menit, guru memberikan kesempatan siswa untuk menanyakan temuan-temuan hasil diskusi.

Pada Fase 5, tahap evaluasi dilakukan pada hari Kamis tanggal 28 April 2015. Waktu yang diperlukan dalam fase ini adalah 70 menit. Guru membagikan nomor undian presentasi dan dilanjutkan dengan presentasi. Siswa diberi kesempatan mempersiapkan presentasi pada laptop masing-masing selama 2 menit. Urutan presentasi adalah kelompok 3, 4, 1, 2, 5 dan 6. Sebelum dilakukan presentasi, guru memberikan arahan yang berbeda dari sebelumnya yaitu siswa wajib bertanya kepada kelompok yang melakukan presentasi setelah presentasi selesai dilakukan. Kelompok yang sedang presentasi diminta untuk mencatat nama penanya, asal kelompok dan pertanyaan yang diungkapkan. Pada akhir fase ini, guru meminta hasil pertanyaan dan jawaban kelompok dikumpulkan.

Dalam pelaksanaan Fase 6, guru membacakan pertanyaan yang bagus dan jawaban yang memuaskan untuk memberikan penghargaan berupa pujian kepada siswa, baik yang menjawab, memberikan tanggapan, maupun kelompok yang telah berpresentasi di depan kelas. Pada fase ini siswa tampak senang dan antusias lebih dari Siklus I.

Tersisa waktu 20 menit, guru memasukkan nilai kelompok,individu dan membacakan di depan siswa. Pembacaan nilai ini diharapkan mampu memberikan motivasi kepada siswa yang belum terpacu untuk aktif menjadi lebih aktif. Selanjutnya guru memberi kesimpulan dan saran dimasa datang.

Berbeda dari Siklus 1, pada Siklus 2 ini telah banyak mengalami perubahan. Hal ini dapat dilihat dari hasil observasi sebagai berikut. Pertama, pada Siklus 2 semua langkah-langkah pembelajaran (fase-fase) telah dilaksanakan. Kedua, pengalokasian waktu tidak sesuai dengan yang direncanakan. Ketiga, terlihat sebagian siswa telah dapat mengikuti pembelajaran dan memperhatikan guru saat menyampaikan materi. Siswa mulai menikmati model belajar ini. Keempat, seluruh siswa aktif dalam pembelajaran. Hal ini terlihat siswa mampu menjawab pertanyaan secara individu dan mengeluarkan pendapatnya, baik pertanyaan dalam presentasi maupun diskusi kelompok. Kelima, minat dan keingintahuan siswa pada perbaikan koneksi jaringan makin bertambah terlihat dari bagaimana siswa berlomba-lomba lebih dulu menemukan solusi kerusakan. Keenam, guru telah memberikan penghargaan kepada siswa yang menjawab ataupun yang bertanya kepada kelompok presentasi selama diskusi berlangsung. Ketujuh, guru menyempatkan diri memberi nilai secara kelompok maupun perorangan. Kedelapan, setelah pelaksanaan pembelajaran berlangsung, dilanjutkan dengan refleksi untuk membahas hasil observasi. Proses pembelajaran yang mengalami perubahan- 
perubahan ke arah yang lebih baik pada pembelajaran dengan metode $S T A D$ setelah 2 Siklus dapat meningkatkan hasil belajar siswa pada pelajaran Diagnosa PC yang terhubung jaringan.

Hasil refleksi antara guru dan peneliti adalah sebagai berikut. Pertama, guru telah memberikan bimbingan kepada siswa saat dalam berdiskusi kelompok. Kedua, guru sudah lebih siap dalam menyampaikan materi maupun praktek dan dapat mengalokasikan waktu dengan baik.

Ketiga, guru mampu membawa situasi belajar menjadi rileks dan menyenangkan terlihat dari siswa yang sudah aktif dalam bertanya dan menjawab pertanyaan dari guru. Suasana pembelajaran dirasakan lebih baik dibandingkan Siklus I. Hal ini tampak dari hasil observasi pada kegiatan belajar-mengajar. Sama halnya dengan Siklus I, untuk melihat hasil belajar dilakukan post-test. Kemampuan akhir siswa dalam menguasai materi Diagnosa PC yang terhubung jaringan setelah melalui pembelajaran dengan tindakan kelas yang berupa pembelajaran dengan model kooperatif $S T A D$ pada sikus I dan 2 mengalami peningkatan (Tabel 3). 
Tabe13

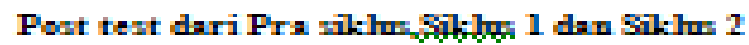

Gra:-xil:

\begin{tabular}{|c|c|c|}
\hline Ha. & Marta Sana & Menta \\
\hline 1 & 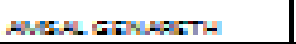 & Mrtan \\
\hline 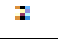 & 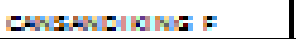 & arten \\
\hline 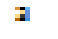 &  & Men \\
\hline+ & arstan & Mtan \\
\hline \pm & Eut & aralle \\
\hline $\mathbf{c}$ & AIUt & when \\
\hline 7 & 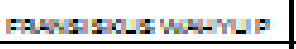 & wtall \\
\hline i & Hagen & arten \\
\hline 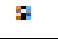 & 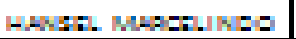 & Grten \\
\hline 18 & - magn-mind. & Mrtan \\
\hline 21 & 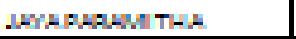 & Futah \\
\hline 12 & 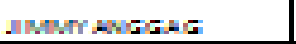 & $1 \mathrm{at}$ \\
\hline 17 & Jomelamaze & Mrtan \\
\hline $1+$ & 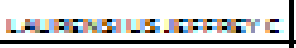 & Mratl: \\
\hline 15 & Bo-and-has & Budatu \\
\hline $\mathbf{1 s}$ & ABN TL. HATE & arall: \\
\hline 17 & acun s-g wT & Audthu \\
\hline 18 & 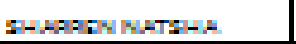 & Mtten \\
\hline $1:$ &  & atall \\
\hline 90 & Thectengumen & H:all: \\
\hline 21 & THEUHA HE: I- & When \\
\hline 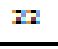 & Whomerales & Heal: \\
\hline 3 & 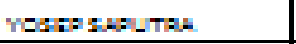 & Mrthen \\
\hline 31 & 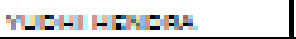 & latat \\
\hline
\end{tabular}

\begin{tabular}{|c|c|c|c|c|c|c|c|c|c|}
\hline \multicolumn{5}{|c|}{ Pu Tindakan } & \multicolumn{3}{|c|}{ Shen 1} & \multicolumn{2}{|c|}{ tant } \\
\hline \multicolumn{3}{|c|}{ LIfhartan } & \multicolumn{2}{|c|}{ MALUTE: } & Ha & Stor & mal & $\mathrm{FII}$ & 2mol \\
\hline$x$ & 1 & stor & 1 & Far & $\mathrm{TM}$ & $T M$ & Gehtr & & \\
\hline I. & so & 30 & ni & in & FE: & Is & no & Tat & \pm \\
\hline L. & +0 & 15 & $\boldsymbol{G}$ & $\pi$ & $7 s$ & II & 6i: & $\mathrm{Ti}$ & It \\
\hline t. & 5 & 24 & 24 & 14 & 10 & 24 & $\boldsymbol{T}$ & 73 & IIt \\
\hline I. & $\mathrm{es}$ & 27 & 25 & 25 & ar: & 25 & GT & Wid & IH \\
\hline t. & $\boldsymbol{\omega}$ & $\because$ & $\mathrm{E}$ & 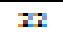 & $\mathbf{\infty}$ & 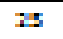 & $\boldsymbol{T}$ & ax: & $=4$ \\
\hline 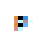 & \pm & $1 \mathrm{r}$ & \pm & $1 \mathrm{a}$ & 75 & III & 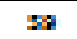 & Wt: & 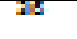 \\
\hline I. & IE: & 14 & 7 & 19 & 73 & III & siz & $\mathrm{mi}$ & 3 \\
\hline t. & $\omega$ & 28 & $\infty$ & 10 & 75 & III & ct & Th & II \\
\hline L. & TS & II: & TS & $\mathbf{I I}$ & $\mathrm{nos}$ & Iit & AII & wh & If \\
\hline I. & $\boldsymbol{\omega}$ & 2 & 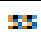 & 2 & $\mathbf{n a}$ & 20 & 70 & 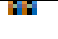 & Int \\
\hline . & Ir & 12 & 5 & $\pi$ & 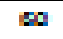 & 2 & 9 & $7 t$ & it: \\
\hline . & $\infty$ & 20 & $\boldsymbol{\omega}$ & 2 & 75 & 21 & $\mathbf{s}$ & Tht & It \\
\hline . & $\mathbf{\infty}$ & is & id & in & $\mathrm{na}$ & II & $\mathrm{Ts}$ & Hit & Frt \\
\hline I. & $\infty$ & 2 & $\mathrm{ma}$ & 20 & an & as & 7 & Hid & \pm \\
\hline t. & $\infty$ & $I$ & 75 & 91 & 7 & In & 75 & $\mathrm{TH}$ & 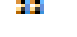 \\
\hline I. & $\mathrm{as}$ & 27 & $\mathrm{na}$ & 7 & 7 & 39 & 78 & $7 \pi$ & 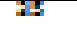 \\
\hline L. & a & in & 75 & II & $\mathrm{7i}$ & a: & $\mathrm{T}$ & At: & $\mathbf{3 x}$ \\
\hline : & + & 1: & TS & I: & $\mathbf{E}$ & 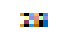 & $\mathbf{m}$ & 75 & it: \\
\hline L. & 75 & 31 & $\mathrm{mi}$ & I: & 20 & IT & 74 & $\mathrm{mi}$ & It \\
\hline I. & $\mathbf{\infty}$ & 2 & $\mathrm{na}$ & 29 & as & 35 & $\mathbf{a}$ & $\mathrm{ta}$ & It: \\
\hline 1. & +0 & 18 & 78 & 31 & $\infty$ & 20 & 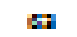 & $\mathrm{mit}$ & It \\
\hline L. & $x$ & $a$ & 7 & I5 & 78 & II & $\mathrm{E}$ & 10 & 7 \\
\hline . & $\rightarrow$ & 18 & $\infty$ & 20 & 185 & 25 & 71 & HE & 7 \\
\hline L. & 7 & II: & is & Ii: & 20 & IT & 78 & A & it \\
\hline
\end{tabular}

Tot:al Nilai

1.135

1.43

1847

1.6091950

Rata-rata

58.7

543

759

57.3 sis

Dari Tabel 3 dapat dilihat perkembangan hasil belajar yang diperoleh oleh siswa saat diberikan post-test, yaitu post-test pada Siklus I, dan post-test Siklus 2. Siswa yang mengalami ketuntasan belajar atau yang memperoleh nilai ketuntasan 75-100 pada Siklus 2 adalah 24 siswa dari total siswa 24. Prosentase siswa yang tuntas sebesar 100 persen. Hasil tindakan pada Siklus 2 menunjukkan bahwa hasil belajar yang didapat sudah mencapai indikator yang ditentukan untuk hasil belajar ( $>50$ persen dari siswa yang mencapai ketuntasan belajar KKM sebesar 75 pada materi yang disampaikan)dan pada proses pembelajaran sudah banyak mengalami perubahan yang lebih baik dari sebelumnya. Berdasarkan hasil kesepakatan antara peneliti dengan guru Diagnosa PC yang terhubung jaringan SMK Bonavita Tangerang, Kota Tangerang, maka Siklus pembelajaran tidak 
dilanjutkan. Peningkatan Hasil Belajar belajar dapat diketahui dari hasil post-test yang diberikan setiap akhir pembelajaran dengan model Kooperatif dengan metode $S T A D$ pada pra tindakan, Siklus I, dan Siklus II (Tabel 4).

Tabel 4. Ketuntasan belajar pada setiap Siklus

\begin{tabular}{|c|c|c|c|c|c|c|}
\hline \multirow{2}{*}{ No } & Siklus & Jumlah Siswa & \multicolumn{2}{|c|}{ Nilai } & \multirow{2}{*}{ Rata-rata kelas } & Ketuntasan belajar \\
\hline 1 & Pra Siklus & 24 & 21 & 3 & 55.7 & 12.5 persen \\
\hline 2 & Siklus 1 & 24 & 18 & 6 & 67.8 & 25 persen \\
\hline 3 & Siklus 2 & 24 & 0 & 24 & 81.8 & 100persen \\
\hline
\end{tabular}

\section{SIMPULAN DAN SARAN}

\section{Simpulan}

Model Kooperatif dengan metode STAD dapat meningkatkan prestasi belajar siswa kelas XI TKJ SMK Bonavita Tangerang. Hasil belajar siswa kelas XI TKJ sebelum dilaksanakan tindakan dengan Model Kooperatif STAD kurang memuaskan. Nilai terendah yang diperoleh siswa 27 dan nilai tertinggi 75 dengan nilai KKM 75. Setelah menggunakan metode koperatif dengan tipe STAD nilai posttest beranjak naik menjadi yang terendah 52 dan yang tertinggi 81 dengan prosentase ketercapaian KKM sebesar 25 persen pada nilai akhir Siklus 1. Sedangkan pada Siklus 2 terdapat nilai minimum sebesar 75 dan maksimum 96 dengan prosentase ketuntasan 100 persen.

\section{Saran}

Pertama, penggunaan metode kooperatif dengan tipe $S T A D$ dapat dijadikan alternatif solusi dalam meningkatkan prestasi belajar oleh guru. Dalam pelaksanaannya guru harus menguasai kemungkinan situasi terburuk yang dialami ketika menggunakan metode tersebut yaitu terjadi situasi yang tidak kondusif saat pembagian kelompok. Guru dituntut untuk merencanakan alokasi waktu untuk setiap fasefase dalam pembelajaran dengan cermat serta mempersiapkan kelompok belajar yang heterogen. 


\section{DAFTAR PUSTAKA}

Arikunto, Suharsimi; Suhardjono dan Supardi. 2006. Penelitian Tindakan Kelas. Jakarta: Bumi Aksara.

Ahmad, Abdul Karim H. 2007. Media Pembelajaran.Makassar: Universitas Negri Makassar.

Departemen Pendidikan Nasional. 2003. Undang-Undang Republik Indonesia No. 20 Tahun 2003 tentang Sistem Pendidikan Nasional. Jakarta

Dimyati. Mudjiono. 2006. Belajar dan Pembelajaran. Jakarta: Rineka Cipta.

Dikmenjur. 2004. Mendiagnosis Permasalahan Pengoperasian PC Yang Tersambung Jaringan. Modul TKJ. Jakarta

Iif Khoiri Ahmadi Sofan Amri, 2010. Proses Pembelajaran Inovatif dan Kreatif dalam Kelas. Jakarta: Prestasi Putakarya

Isjoni.2010.Cooperative Learning Evektivitas Pembelajaran Kelompok. Bandung: Alvabeta

Mulya, Hamdani. 2012. Metode Pembelajaran Kooperatif. STAIN Malikussaleh Lhokseumaweh: Unimal

Nawawi, Hadari. 2007.Metode Penelitian Bidang Sosial.Yogyakarta: Percetakan Universitas Gajahmada

Riyanto, Yatim. 2010. Paradigma Baru Pembelajaran. Jakarta: Kencana

Robert E.Slavin.2010. Cooperative Learning.Bandung : Nusa Media

Sagala, Syaiful. 2007. Konsep dan Makna Pembelajaran. Bandung: Alfabeta.

Surya, Mohammad. 2003. Psikologi Belajar dan Pembelajaran. Jakarta: CV. Mahaputra Adidaya.

Sugiyono. 2011. Metode Penelitian Kuantitatif, Kualitatif dan R\&D. Bandung: Alfabeta

Syaiful Bahri Djamarah, Prestasi Belajar dan Kompetensi Guru, Surabaya : Usaha Nasional,1994

Trianto. 2011.Panduan Lengkap Penelitian Tindakan Kelas (Classrooom Action Research).Surabaya:Prestasi Pustakaraya 